\title{
ARTYKULY - ARTICLES - PAPERS
}

„TURYZM", t. 8, z. 2, 1998

Jolanta Latosinska

\section{PRZESTRZEŃ TURYSTYCZNA ŁODZIAN \\ L'ESPACE TOURISTIQUE DES HABITANTS DE ŁÓDŹ \\ THE TOURIST SPACE OF THE INHABITANTS OF LODZ}

\begin{abstract}
Artykuł jest próbą określenia przestrzeni turystycznej łodzian połowy lat dziewięćdziesiatych. Na potrzeby niniejszych rozważań wykorzystano dorobek Katedry Geografii Miast i Turyzmu UŁ (prace teoretyczne i aplikacyjne) z zakresu badań nad wypoczynkiem mieszkańców Łodzi. Uzyskane wyniki porównano $\mathrm{z}$ wynikami $\mathrm{z}$ lat osiemdziesiątych. Przestrzeń turystyczna łodzian zostala zidentyfikowana na podstawie miejscowości i obszarów odwiedzanych podczas wyjazdów urlopowo-wakacyjnych, krajoznawczych oraz specjalistycznych, zaprezentowanych $w$ artykule $w$ podziale na regiony.
\end{abstract}

Badania nad wypoczynkiem mieszkańców Łodzi w łódzkim ośrodku geograficznym prowadzone są od końca lat siedemdziesiątych. Od tego czasu powstało kilkanaście prac zarówno o charakterze teoretycznym, jak i aplikacyjnym, głównie jako prace magisterskie czy doktorskie. Można tu wymienić studia: A. B a lcerak 1996, D. B ednarskiej 1978, E. D zi egi éc, S. L is zewskiego 1985, M. Gwa dery 1996, D. K e gle r 1990, A. Koperkiewicza 1980, A. Matczaka 1993, 1994, M. Miazek-Kajkowskiej 1988, M. S a ltarskiej 1991, W. S ibery 1977, M. Szczegielskiej 1989, A. Szymańskiej 1995, E. Zmysłowskiej 1994, J. Kostrzewy 1991, J. Latosińskie j 1997a, b, R. Wilus i a 1991, M. Pawlak 1990, P. Lewandoskiego 1993, E. Walborskiej 1995, W. Rogalskiego 1995, M. Kołodziejczyka 1997, K. Denys-Skupieńskiej 1997, A. M i c h a l a k 1998. Prace te zawieraja istotną dla podjętego tematu, analizę rozkładu przestrzennego, wyznaczają regiony koncentracji miejsc wypoczynku urlopowo-wakacyjnego, weekendowego oraz wycieczkowego mieszkańców Łodzi wg grup społecznych, zawodowych, miejsc zamieszkania (osiedle 
mieszkaniowe), jak również preferowane kierunki wyjazdów wypoczynkowo-poznawczych proponowane przez łódzkie biura podróży.

Od kilku lat jednym z nurtów zainteresowań geografii turyzmu są badania nad przestrzenią turystyczną. Powstało wiele definicji, które dziś uważa się już za klasyczne. Dotyczy to zwłaszcza przestrzeni geometrycznej zdefiniowanej przez Newtona i Kanta (S t a c h o w s k i 1993), a do której odwołują się często geografowie w swoich badaniach (C h o j n i c ki 1974, D o mań s k i 1965, D z i e wońs k i 1967a, b, Les z c z y c k i 1972).

Przyjmując założenie, że obszarem wszelkiej działalności człowieka jest właśnie przestrzeń trójwymiarowa (fizyczna) - której doświadczamy - geografowie wyróżniają najczęściej pięć głównych rodzajów przestrzeni: geodezyjna, geograficzną, ekonomiczna, społeczno-ekonomiczną i społeczna. Literatura geograficzna bardzo szeroko omawia każdą $\mathrm{z}$ wymienionych rodzajów przestrzeni (D z i e w oń s k i 1967a, b, 1988, Le szczy c k i 1972, B e re zow s k i 1969, Dom ański 1965, 1990, Otok 1987, Wallis 1983, 1990, Grzeszczak 1971, Bartkowski 1974, Wojciechowski 1986 , J a ł o w i e c k i 1986, D r a m ow i c z 1984), co nie oznacza, że istnieje pełna zgodność w tym zakresie.

W ramach przestrzeni geograficznej została wyróżniona przestrzeń turystyczna. Wydzielenie takiej przestrzeni zostało sprowokowane analiza zjawiska turystyki, interpretowanego jako pokonywanie przestrzeni przez człowieka w celach wypoczynkowych, poznawczych, doznania przeżyć, przy zachowaniu dobrowolności i czasowej zmiany miejsca zamieszkania. Poza aspektem przestrzennym turystyka to zjawisko społeczno-kulturowe oraz ekonomiczne (P r z e c ław s k i 1994, R oga lewski 1977 , L is zews ki 1995a, M a t c zak 1992, G aw or e c k i 1994).

W geografii turyzmu ,przestrzeń" stanowi zarówno jedno z podstawowych pojęć, jak i ważne zagadnienie badawcze. Najczęściej spotykane ujęcia przestrzeni turystycznej można określić jako: funkcjonalne (W a r s z y ń s k a, J a c kowski 1978, Warszyńska 1986, Stachowski 1993, Li szewski 1995b, D z i e gi éc 1995, Stalsk i 1984) lub systemowe (M a tczak 1992, Hus band s 1983, M i os s e c 1977). Bliskie problemowi badawczemu podjętej pracy są teoretyczne rozważania wywodzące definicje przestrzeni turystycznej z teorii przestrzeni geograficznej (W a r s z y ń ska, J a ckowski 1978, W a rszyńska 1986, L is z ewski 1995b). J. W a rszyńska i A. Ja ckowski (1978) definiują przestrzeń turystyczną jako część przestrzeni geograficznej i społeczno-ekonomicznej, w której zachodzą zjawiska turystyczne. W innej pracy J. W a r s z y ń s k a (1986) uważa przestrzeń turystyczną za przestrzeń geograficzną (fizycznogeograficzną i społeczno-gospodarcza), w której zachodzą zjawiska turystyczne.

Zdaniem autorki, najbardziej wyczerpującą definicję przestrzeni turystycznej formułuje S. L is ze w sk i (1995b) w artykule Przestrzeń turystyczna. 
Według tego autora: „Przestrzeń turystyczna jest funkcjonalnie wyróżniającą się częścią (podprzestrzenia) przestrzeni geograficznej rozumianej w sensie largo, to znaczy jako przestrzeń, na którą składają się elementy przyrodnicze powłoki Ziemi (środowisko naturalne), trwałe efekty działalności ludzkiej w tym środowisku (środowisko gospodarcze), a także środowisko człowieka w rozumieniu społecznym” (s. 94). W dalszej części artykułu autor wskazuje, iż „motywem jej powstania i rozwoju są potrzeby wypoczynku, poznanie i doznanie przeżyć" (s. 94).

Jak słusznie zauważył J. S t a c h o w s k i (1993) w artykule $O$ pojmowaniu przestrzeni $w$ geografii turyzmu, termin ten ,mimo swego niewatpliwie podstawowego charakteru, nie należy do terminów często stosowanych" (s. 171). Zamiennie używane są terminy: „obszar", „terytorium", "region”, ,rejon”, „miejscowość", czyli synonimy przestrzeni geograficznej, tyle że z określeniem przymiotnikowym: ,turystyczny (-a)".

Tak rozumiana przestrzeń turystyczna (miejscowości i regiony czy obszary turystyczne poza miejscem zamieszkania) pozostaje przedmiotem niniejszych rozważań, podmiotem zaś człowiek, ponieważ to on właśnie w swoich zachowaniach turystycznych wybiera obszar, region, miejscowość, zakreślając tym samym przestrzeń wypoczynku w czasie wolnym od pracy, obowiązków służbowych i społecznych. Uwzględniając czas wypoczynku, a także jego cel i formę, przestrzeń turystyczną można określać jako: urlopową, weekendową, wypoczynku codziennego czy pobytową (wypoczynkowa), krajoznawczą, specjalistyczna.

W niniejszej pracy przestrzeń turystyczna rozumiana jest jako część przestrzeni geograficznej (podprzestrzeń), czyli jakościowo zróżnicowanej powierzchni Ziemi, której walory środowiska naturalnego oraz antropogenicznego stwarzają możliwości wypoczynku niezbędnego do normalnego funkcjonowania organizmu, a której wybór należy do człowieka. Tak pojęta przestrzeń $\mathrm{z}$ jednej strony ma charakter obiektywny (środowisko naturalne $\mathrm{i}$ antropogeniczne), z drugiej zaś subiektywny, bowiem o jej identyfikacji decyduje człowiek, dokonując jej wyboru. Może to oznaczać, że człowiek kreuje-tworzy swoją przestrzeń wypoczynkową (L a t o s i ń s k a 1997b). W tym znaczeniu przestrzeń jest środowiskiem, w którym człowiek realizuje własne potrzeby wypoczynkowe zaspokajając różnorodne "gusty i snobizmy rekreacyjne" (S t a l s k i 1984). Przestrzeń turystyczna (wypoczynkowa), szczególnie zaś urlopowa, wycieczkowa czy weekendowa ma swoją cenę, a jej wybór jest zdeterminowany czynnikami ekonomicznymi, społecznymi, demograficznymi, geograficznymi, osobowościowymi i psychosomatycznymi (Krzy mow ska-Kost rowi ck a 1995, L a t o s i ń s k a 1997a, b). Zakładając, że przestrzeń rekreacji pojawiła się na pewnym etapie cywilizacyjnego rozwoju $\mathrm{w}$ dobie industrializacji i urbanizacji (J a ł o w i e c k i 1988) i nie jest dostępna w jednakowym dla każdego człowieka zakresie, można warunki wypoczynku mieszkańców aglomeracji traktować jako świadczące o standardzie życia człowieka. Szczególnego zna- 
czenia nabiera wypoczynek na obszarach odlegtych od miejsca zamieszkania, ponieważ świadczy on nie tylko o potrzebie, ale głównie o możliwościach ekonomicznych i organizacyjnych człowieka ( $\mathrm{L}$ i s z e w s k i 1995a).

U podstaw wszelkiej działalności człowieka, w tym również zachowań turystycznych, leży zespół potrzeb i dążeń ludzkich; potrzeba wypoczynku, poznania, doznania. W przypadku mieszkańców dużych aglomeracji, gdzie warunki życia i pracy były i są nadal trudne i uciążliwe (L a t o s i ń s k a 1997a), można mówić nie tylko o potrzebie, lecz wręcz konieczności wypoczynku poza miejscem zamieszkania (D z i e g i e ć, L i s z e w s k i 1985). Lódź jest przykładem dużego miasta, aglomeracji miejsko-przemysłowej, gdzie realizacja potrzeb wypoczynkowych wymaga zmiany środowiska, rozproszenia $\mathrm{w}$ przestrzeni oraz zmiany czynności. Zewnętrznym przejawem realizacji potrzeb turystycznych (wypoczynkowych) miejskiego społeczeństwa jest ucieczka z miasta w początku sezonu letniego, wakacji zimowych oraz podczas świąt i weekendów.

J. Z d e b s k i (1996) w badaniach z zakresu psychologii turystyki uważa, iż „żyjący w wielkich aglomeracjach miejskich ludzie częstokroć pozbawieni zostali tak podstawowych potrzeb, jak czyste powietrze, słońce, zieleń, woda", czyli w wyniku procesów urbanizacyjnych zerwana została więź pomiędzy człowiekiem a jego naturalnym środowiskiem przyrodniczym. Stąd, dla zachowania zdrowia fizycznego i psychicznego, niezbędny jest racjonalny wypoczynek w czystym ekologicznie środowisku, a wyjazdy weekendowe, szczególnie zaś wakacyjne czy urlopowe, stanowią niewątpliwie okazję do opuszczenia ,zatłoczonego i hałaśliwego miasta”. Turystyka jako jedna z form wypoczynku, poza czasową zmianą miejsca zamieszkania, zmianą środowiska, dostarcza silnych przeżyć poznawczych, emocjonalnych, estetycznych, jest okazją do odprężenia psychicznego, likwiduje napięcie i uwalnia od pośpiechu towarzyszącego codziennemu życiu - pod warunkiem, że wyzwala emocje dodatnie. Poprzez turystykę realizuje się zaspokojenie pragnienia wiedzy i rozumienia oraz potrzeby doznań estetycznych, co jest szczególnie ważne dla rozwoju człowieka. Jednak potrzeba rekreacji i jej realizacja należą do „skrajnie zindywidualizowanych" (B r e c ła w i k 1988), co nastręcza wielu trudności badaczom zachowań turystycznych. Bardzo trafnie zauważyli D. J. W a I m s l e y i G. J. L e w i s (1997), cytując za Youngiem i Wilmottem (odwołując się do ich publikacji z 1973 r.), iż opis i pomiar działalności w czasie wolnym można porównać do „próby złapania meduzy gołymi rękami”. Dotyczy to zarówno zachowań w czasie wolnym, jak i motywów uprzednio dokonywanego wyboru miejsca spędzenia urlopu, które można zawsze interpretować niejednoznacznie. Pomimo iż każde działanie człowieka jest umotywowane, to ludzie nie zawsze są świadomi motywów kierujących ich wyborem. W badaniach nad motywacją uprawiania turystyki trudno jest jednoznacznie określić, czy źródłem motywacji jest to, co turystę przyciagga - wszelkiego rodzaju atrakcje turystyczne - czy to, co popycha go do wyjazdu, czyli cały zespół potrzeb, dążeń i zainteresowań (W i n i a r s k i 1988). 
Ze względu na brak danych obrazujących zjawisko wypoczynku i preferencji wyjazdowych mieszkańców Łodzi w skali całego miasta, w analizie przestrzeni turystycznej lodzian połowy lat dziewięćdziesiątych posłużono się badaniami cząstkowymi, których wyniki znajdują się w pracach magisterskich: A. Sz y m án ski ej (1995) Model turystyki $i$ wypoczynku mieszkańców osiedla Radogoszcz Zachód w Łodzi, E. Z m y s ł o w s k i e j (1994) Turystyka i wypoczynek mieszkańców osiedla Stare Chojny oraz pracy doktorskiej J. L a to s i ń s k i e j (1997) Przestrzeń urlopowo-wakacyjna pracowników wyższych uczelni Lodzi. Pozostałe prace wykonane w ośrodku łódzkim wymienione we wstępie posłużą jako materiał porównawczy i uzupełniający. Wspomniane prace zawierają dane dotyczące połowy lat dziewięćdziesiątych. Wykonane zostały w latach 1994-1997 na podstawie badań z lat 1993-1995. W doborze próby do badań zastosowano metodę reprezentacyjną. Wielkość próby do badań w przypadku mieszkańców osiedli Stare Chojny i Radogoszcz Zachód oraz pracowników wyższych uczelni Łodzi stanowiła $8 \%$ całej analizowanej zbiorowości. Badane populacje są zróżnicowane pod względem demograficznym, społecznym, zawodowym, ekonomicznym i zajmują różne miejsce w strukturze przestrzennej miasta. Badania przeprowadzono metodą wywiadu kwestionariuszowego. W przypadku badań w osiedlach mieszkaniowych były to ankiety rodzinne, a w przypadku pracowników wyższych uczelni ankieta personalna. Łącznie przeankietowano 2668 osób. Wśród mieszkańców osiedla Stare Chojny przeprowadzono 342 ankiety rodzinne obejmujące 1082 osoby. Wśród mieszkańców osiedla Radogoszcz Zachód przebadano 786 osób wykonując 244 ankiety. Badania pracowników wyższych uczelni (UL, PŁ, Akademia Medyczna, Akademia Muzyczna, PWSFTiT, PWSSP) objęły 800 osób spośród 9817 zatrudnionych i prowadzone były w pięciu formalnie wydzielonych grupach pracowniczych - od pracowników naukowo-dydaktycznych począwszy, na pracownikach obsługi kończąc (L a t o s ińs k a 1997b).

\section{CHARAKTERYSTYKA SPOLECZNO-EKONOMICZNA BADANYCH ZBIOROWOŚCI}

Osiedle Radogoszcz Zachód usytuowane jest w północno-zachodniej części miasta, w dzielnicy Bałuty. Wybudowane zostało w końcu lat siedemdziesiątych i latach osiemdziesiątych. Społeczność zamieszkująca to osiedle to w $51,6 \%$ kobiety. Analiza struktury wieku wykazała, że najliczniejszą grupę stanowią mieszkańcy w wieku 40-49 oraz 30-39 lat i odpowiadająca im grupa dzieci i młodzieży w wieku szkolnym (10-19 lat). Pod względem demograficznym jest to osiedle młode. 
Osoby w wieku produkcyjnym stanowią 64,6\% mieszkańców, natomiast w wieku poprodukcyjnym $2,1 \%$. Najliczniejszą grupę czynnych zawodowo $(53,4 \%)$ stanowią robotnicy $(24,6 \%)$. Struktura wykształcenia mieszkańców osiedla wykazuje, iż w 36,5\% posiadają wykształcenie średnie, $29,9 \%$ ukończone podstawowe, $14,6 \%$ wyższe. Prawie $25 \%$ ankietowanych to robotnicy, a co dwudziesty respondent to właściciel zakładu lub handlowiec. Pracownicy umysłowi oraz osoby z wykształceniem wyższym stanowią $23,9 \%$. Biorąc pod uwagę poprzednie miejsce zamieszkania są to głównie dawni mieszkańcy Bałut (43\%) i Śródmieścia (21\%), w mniejszym zaś stopniu Polesia (16\%), Widzewa (10\%) i Górnej (8\%). Kilkanaście rodzin (13 wśród badanych) pochodzi spoza Lodzi, głównie województw sąsiednich. Mieszkańcy osiedla należą do średnio zamożnej klasy mieszkańców Łodzi. Wyższy poziom materialny prezentują osoby z wykształceniem wyższym i średnim. Posiadacze samochodu to w ponad $70 \%$ osoby z wykształceniem średnim $(40,1 \%)$ i wyższym $(36,7 \%)$.

Osiedle Stare Chojny usytuowane jest w południowej części miasta, w dzielnicy Górna. Wybudowane zostało w większości w latach osiemdziesiątych (65\% zabudowy). Analiza struktury płci społeczności osiedla wykazuje (podobnie jak w poprzednim przypadku) nieznaczną przewagę liczby kobiet $(52,2 \%)$ nad mężczyznami. Jest to młoda demograficznie jednostka osiedlowa. Najliczniejsza grupę stanowią osoby w wieku 35-44 lata oraz odpowiadające im dzieci w wieku szkoły podstawowej i średniej (10-19 lat). W wieku produkcyjnym znajduje się $62,1 \%$ mieszkańców tego osiedla, a w wieku poprodukcyjnym 5,5\%. Czynni zawodowo stanowią 49,1\% badanej zbiorowości, wśród których najliczniejsza grupa to robotnicy $-21,6 \%$. Wykształcenie mieszkańców osiedla Stare Chojny kształtuje się na podobnym poziomie jak mieszkańców osiedla Radogoszcz Zachód: osoby z wykształceniem średnim stanowią $38,1 \%$ badanej zbiorowości, podstawowym $27,3 \%$, wyższym - $10,8 \%$. W obu przypadkach jest to poziom nieco wyższy niż ogólny dla miasta. Mieszkańcy osiedla Stare Chojny pochodzą w 33,9\% z dzielnicy Górna (zmiana miejsca zamieszkania w granicach tej samej dzielnicy), w 26,8\% Bałut, 15,3\% Widzewa, 13,4\% Polesia i tylko w 10,4\% Śródmieścia. Kilkanaście rodzin (11 wśród badanych) pochodzi spoza Łodzi Pabianic, Rzgowa, Piotrkowa Trybunalskiego, Poznania, Czerniejewa, Kalisza, Torunia, jak również Szczecina i Nowego Targu.

Społeczność pracowników wyższych uczelni Łodzi stanowią zatrudnieni w pięciu formalnie wydzielonych grupach: pracowników naukowo-dydaktycznych - samodzielnych (10\%) i pomocniczych $(39 \%)$, pracowników inżynieryjno-technicznych (21\%), obsługi $(16,8 \%)$ i administracji $(12,6 \%)$. Wszyscy badani respondenci to osoby czynne zawodowo. Analiza struktury płci badanych respondentów wykazuje ogólnie wyrównany jej poziom - 49,5\% stanowią mężczyźni i 50,5\% kobiety. Przewagę liczby kobiet nad liczbą mężczyzn obserwuje się w grupach wiekowych 31-40 i 41-50 lat oraz zależność odwrotną we wszystkich grupach pracowników naukowo-dydaktycznych. Najliczniejszą grupę sta- 
nowią pracownicy w wieku 31-40 i 41-50 lat. Rozbieżności w strukturze wieku poszczególnych grup pracowników występują głównie pomiędzy reprezentantami grupy samodzielnych (wszyscy mają powyżej 40 lat) i pomocniczych (wszyscy mają powyżej 24 lat) pracowników naukowo-dydaktycznych oraz pozostałych grup, których pracownicy reprezentowani są we wszystkich przedziałach wiekowych. Dominujący model rodziny wśród pracowników to rodziny z jednym czy dwójką dzieci (70\%) lub osoby bezdzietne (25\%). Analiza wykształcenia badanych respondentów obrazuje specyfikę struktury zatrudnienia w wyższych uczelniach. Wśród badanej grupy aż $64,2 \%$ to osoby z wyższym wykształceniem (prawie sześć razy więcej niż wśród mieszkańców badanych osiedli). Wykształceniem średnim i policealnym legitymuje się $23,2 \%$, zasadniczym i podstawowym odpowiednio $6,1 \%$ i $6,4 \%$. Samodzielni i pomocniczy pracownicy naukowo-dydaktyczni, co jest oczywiste, w $100 \%$ posiadają wykształcenie wyższe. W 93,2\% badani respondenci to mieszkańcy Łodzi: w $32,1 \%$ mieszkańcy Bałut, 20,4\% Polesia, 17\% Śródmieścia, 16,8\% Górnej i tylko $13,5 \%$ Widzewa. Pozostali są mieszkańcami 28 miejscowości położonych głównie w najbliższych jej okolicach. Porównując średnie zarobki badanych grup ze średnią krajową można zauważyć, że w 1994 r. tylko średnie zarobki pracowników naukowo-dydaktycznych przekraczały poziom średniej krajowej - od $199 \%$ dla profesorów do $109 \%$ dla asystentów. Zarobki pozostałych grup pracowników kształtowały się na poziomie od $80 \%$ dla pracowników inżynieryjno-technicznych i administracji do 66\% średniej krajowej dla pracowników obsługi - najsłabiej uposażonej grupy wśród całej badanej populacji. Dobra posiadane przez pracowników wyższych uczelni to głównie samochód - 59\%, mieszkanie własnościowe - 47\%, działka letniskowa - 23\%, domek letniskowy - 16,6\% (najliczniej przez pracowników naukowo-dydaktycznych).

\section{PRZESTRZEŃ TURYSTYCZNA}

Przestrzeń turystyczna łodzian to miejscowości i obszary turystyczne poza stałym miejscem zamieszkania, zakreślona podczas wyjazdów turystycznych: urlopowo-wakacyjnych, weekendowych i wycieczkowych. Wypoczynek urlopowo-wakacyjny od życia wielkomiejskiego zajmuje miejsce szczególne, jest to bowiem okres wolny od pracy trwający nieprzerwanie średnio 26 dni roboczych (42 dni dla pracowników naukowo-dydaktycznych wyższych uczelni). Długość urlopu precyzyjnie określa Kodeks Pracy (1996) i „Dziennik Ustaw Rzeczypospolitej Polskiej" (1990).

Autorka przyjmuje w swoich badaniach, że wyjazd urlopowo-wakacyjny to wyjazd poza miejsce zamieszkania, trwający co najmniej 7 dni, wychodząc z założenia, że jest to minimalny czas potrzebny dla adaptacji człowieka do innego 
środowiska, co jest warunkiem racjonalnego i efektywnego wypoczynku. W przypadku mieszkańców Łodzi dostępność najatrakcyjniejszych walorów wypoczynkowych - morze, góry, jeziora - mieści się praktycznie w czasie jednodniowego dojazdu, co znacznie skraca czas efektywnego wypoczynku. Występująca obecnie na świecie tendencja do skracania długości wyjazdów urlopowych, a za to zwiększania ich częstotliwości, pozwala na traktowanie już okresu pięciu dni jako wypoczynku urlopowego.

Udział w wyjazdach urlopowych (krajowych i zagranicznych) ludności Polski kształtował się w ostatnich latach na poziomie ok. 40\% (Turystyka w 1994 r). Wskaźnik aktywności urlopowej (stosunek procentowy liczby osób uczestniczących w wyjazdach urlopowo-wakacyjnych do ogólnej liczby osób badanej grupy) wśród grup badanej populacji kształtował się na poziomie $71 \%$ dla pracowników wyższych uczelni (od powyżej $80 \%$ dla pracowników naukowo-dydaktycznych do $41 \%$ dla pracowników obsługi), $52,2 \%$ dla mieszkańców osiedla Radogoszcz Zachód, 46,5\% dla mieszkańców osiedla Stare Chojny. Przyjmując prognozy S. Ostrowski e go (1980) można uznać potrzeby wypoczynkowe w pełni zaspokojone wśród pracowników naukowo-dydaktycznych wyższych uczelni, ponieważ wskaźnik aktywności urlopowo-wypoczynkowej wymienionych grup ksztaltował się na poziomie przekraczającym $80 \%$. Wśród pozostałych grup można mówić o zaspokojeniu potrzeb wypoczynkowych na poziomie dostatecznym. Należy zauważyć, iż w rozwiniętych gospodarczo krajach EWG uczestnictwo w wyjazdach urlopowych w 1989 r. (10 lat temu) kształtowało się już na poziomie $60-65 \%$. W Hiszpanii i Portugalii zbliżone było do wskaźnika dla Polski i wynosiło odpowiednio 44\% i 31\%. Wyjazdy turystyczne łodzian charakteryzują się bardzo dużą sezonowością. Gros wyjazdów urlopowo-wakacyjnych zrealizowano w lipcu i sierpniu (ok. 90\%). Wyjazdy wycieczkowe realizowano głównie w sezonie wiosennym i jesiennym, natomiast wyjazdy weekendowe od kwietnia do października. $Z$ wypoczynku zimowego łodzianie korzystają nielicznie. Najczęściej z dwukrotnych wyjazdów w ciągu roku korzystały dzieci i młodzież (zimowiska, obozy narciarskie, kolonie itd.). Niewątpliwie na częstotliwość wyjazdów w ciagu roku największy wpływ mają sytuacja finansowa oraz przyzwyczajenie. Rodzice często rezygnują z własnego wypoczynku bądź korzystają z tańszych możliwości, udostępniając tym samym wypoczynek dzieciom. Głównym motywem wyjazdu na wypoczynek wakacyjny i weekendowy pozostaje potrzeba zmiany środowiska, podróży wycieczkowych chęć poznania, natomiast wybór miejsca zależy od przyzwyczajenia, względów rodzinnych, kontaktów towarzyskich, uwarunkowań zdrowotnych i czynników bliżej nieokreślonych przez respondentów. Oczywiście możliwość wyjazdu i wybór miejsca determinowany jest często względami finansowymi. Dominująca forma wypoczynku mieszkańców Łodzi to: wczasy, pobyt we własnym domku letniskowym, turystyka wycieczkowa i kwalifikowana, pobyt u rodziny na wsi i w mieście. Łodzianie najczęściej na wypoczynek urlopowy wyjeżdżają 
z rodziną, a wyjazdy organizowane są w większości indywidualnie. Często są to wczasy zorganizowane, lecz wykupione indywidualnie. Im wyższy poziom wykształcenia badanej grupy, tym wyższy poziom deklaracji indywidualnej organizacji wypoczynku: od $83 \%$ wśród pracowników wyższych uczelni do $52,5 \%$ w przypadku mieszkańców osiedla Radogoszcz Zachód. Częściej z pośrednika (biura podróży, szkoły, zakładu pracy) korzystano w przypadku wyjazdów krajoznawczych, a szczególnie zagranicznych. Preferowany środek lokomocji to samochód, następnie PKP, PKS, autokar biura turystycznego i biura przewozowego.

Dla znacznej części mieszkańców Łodzi miejscem wypoczynku było miejsce zamieszkania - od $29 \%$ wśród pracowników wyższych uczelni do $53 \%$ wśród mieszkańców osiedla Stare Chojny. Przyczyny pozostania w domu były różnorodne, lecz zdecydowanie najczęściej o pozostaniu w mieście decydowały trudności finansowe (ok. 60\% respondentów pozostających w Łodzi deklarowało takie uwarunkowanie), które w przypadku każdej badanej grupy wymieniano na pierwszym miejscu. Kolejne przyczyny pozostania w domu to sytuacja rodzinna, brak czasu, stan zdrowia, brak urlopu, dodatkowa praca zarobkowa.

Analiza struktury wyboru regionów pozwala zauważyć, iż najwięcej wyjazdów urlopowo-wakacyjnych zrealizowano nad morze i w tzw. „inne regiony”, co należy rozumieć jako Polskę Środkową i pozostałe regiony. Mniej preferowany przez łodzian był region górski i pojezierny.

Zakreśloną podczas wyjazdów przestrzeń wypoczynku urlopowo-wakacyjnego można podzielić na krajową i zagraniczną. Zdecydowaną większość (od $95 \%$ dla mieszkańców analizowanych osiedli mieszkaniowych do $84 \%$ dla pracowników uczelni łódzkich) ogółu wyjazdów stanowiły wyjazdy krajowe, podczas których odwiedzono miejscowości w różnych regionach Polski. Szczegółowa analiza przestrzeni (tab. I, rys. 1) wypoczynkowej badanej grupy została przedstawiona w podziale na pięć regionów.

Wyjazdy urlopowe fodzian (\%)

T a b e la I

Les départs de congé des habitants de Łódź (\%)

\begin{tabular}{|l|c|c|c|}
\hline \multirow{2}{*}{ Region } & \multicolumn{3}{|c|}{ Grupa } \\
\cline { 2 - 4 } & $\begin{array}{c}\text { pracownicy wyższych } \\
\text { uczelni }^{\mathrm{a}}\end{array}$ & $\begin{array}{c}\text { mieszkańcy osiedla } \\
\text { Stare Chojny }\end{array}$ & $\begin{array}{c}\text { mieszkańcy osiedla } \\
\text { Radogoszcz Zachód }\end{array}$ \\
\hline Morze & 23,8 & 23,6 & 33,4 \\
Góry & 20,6 & 17,8 & 15,1 \\
Jeziora & 15,3 & 13,1 & 14,5 \\
Polska Środkowa & 25,2 & 20,9 & 30,6 \\
i pozostale regiony & 15,4 & 5,1 & 6,4 \\
\hline Turystyka & & & \\
zagraniczna & & & \\
\hline
\end{tabular}

Źród lo: a J. La tos ińska (1997), ${ }^{b}$ E. Z m y słowska (1994), ${ }^{c}$ A. S z y m a ń s k a (1995). 

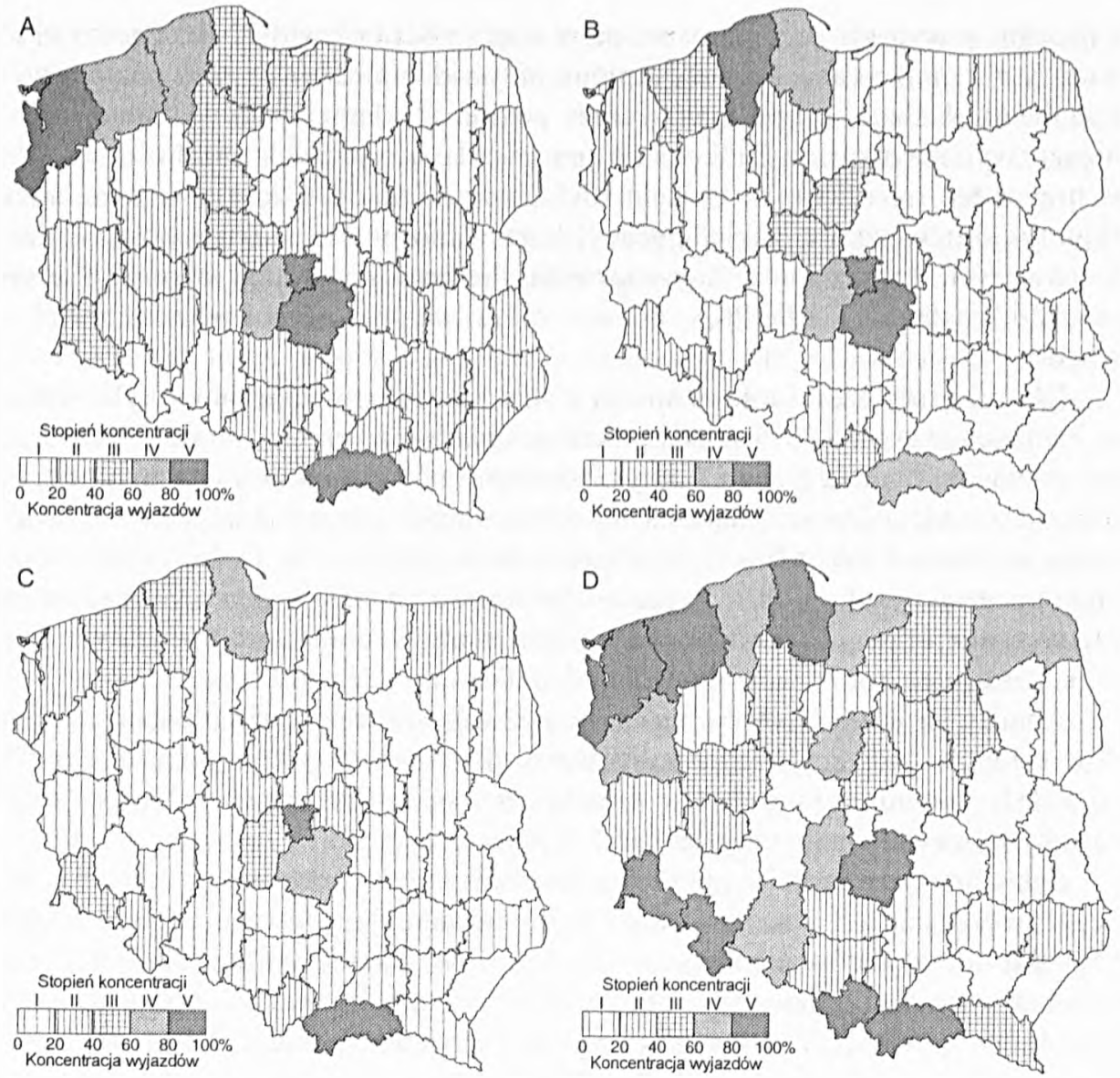

Rys. 1. Koncentracja wyjazdów urlopowo-wakacyjnych (wypoczynkowych) łodzian w latach dziewięćdziesiątych; a - mieszkańców osiedla Radogoszcz Zachód (S z y m a ń s k a 1995), b mieszkańców osiedla Stare Chojny ( $\mathrm{Z}$ m y s ł o w s k a 1994), c - pracowników wyższych uczelni (L a t o s i ń s k a 1998), d - koncentracja wyjazdów wypoczynkowych mieszkańców

Łodzi w 1981 r. (D z i e g i e ć, L i s z e w s k i 1985)

Dessin 1. La concentration des départs de congé et de vacances (de repos) des habitants de: a - la cité residentielle Radogoszcz Zachód (S z y m a ń s k a 1995); b - la cité residentielle Stare Chojny ( $\mathrm{Z}$ m y s ł o w s k a 1994); c-des travailleurs des écoles supéieures à Łódź (L a t o $\mathrm{s}$ i ń s k a 1998), d - la concentration des départs de congé et de vacances des habitants à Lódź en 1981 (D z i e g i éc, L is z ewsk i 1985)

Na obszarze Polski wyróżniono cztery główne regiony geograficzne układające się równoleżnikowo: morze, góry, pojezierza oraz pozostałe regiony, natomiast miejscowości i obszary odwiedzone podczas wyjazdów zagranicznych potraktowano łącznie jako piąty region. Podczas wyjazdów zagranicznych odwiedzono prawie wszystkie kraje europejskie oraz kilkanaście poza Europa. 

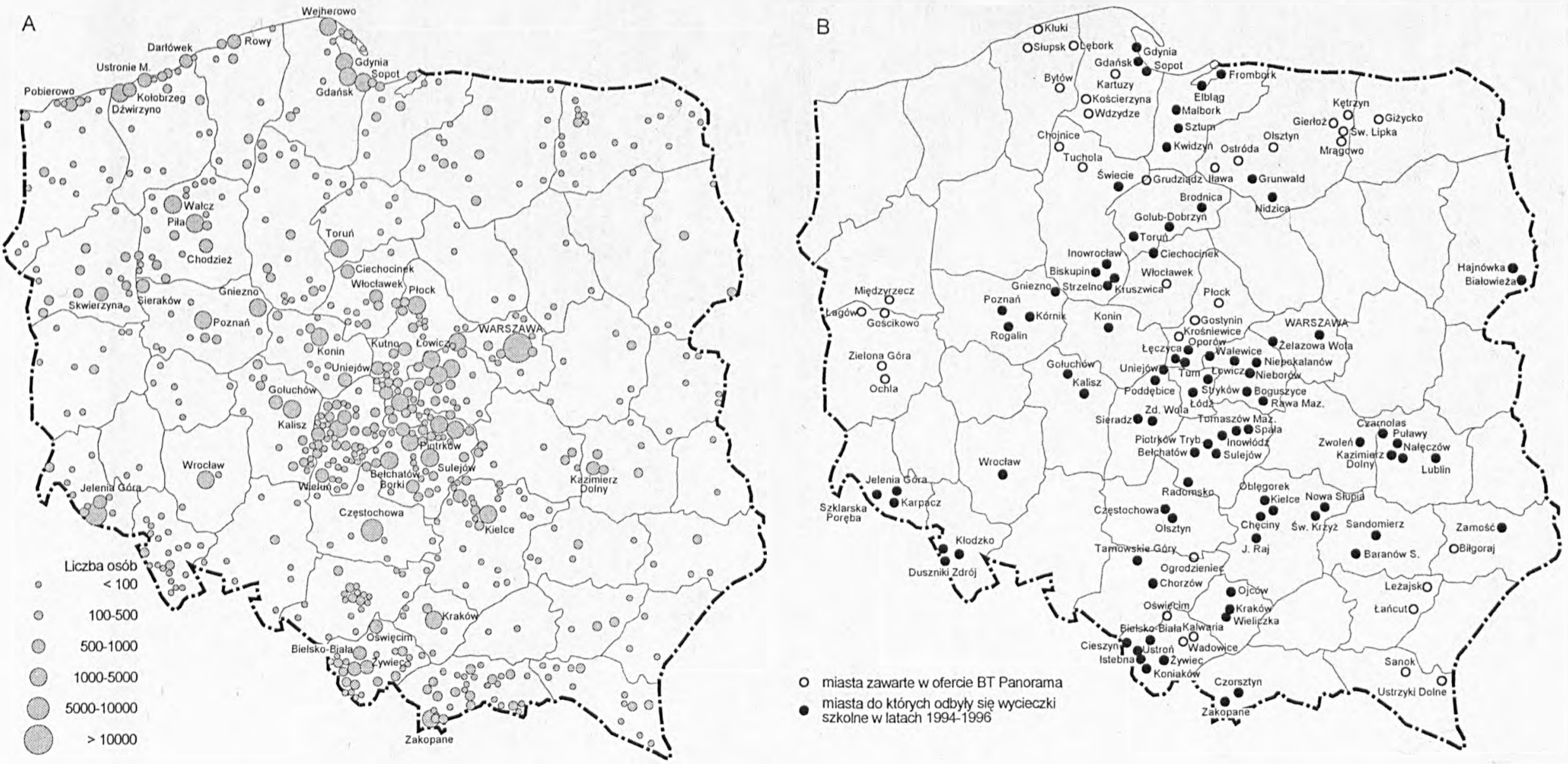

Rys. 2. Wyjazdy krajoznawcze mieszkańców Lodzi; a- wyjazdy krajoznawcze mieszkańców Lodzi w 1988 r. (K o s t r z e w a 1991); b - wycieczki szkolne zorganizowane przez biuro turystyczne "Panorama" w latach 1994-1996 (D e n y s - S k u p i én s k a 1997)

Dessin 2. Les départs chorographiques des habitants de Łódź; a - les départs chorographiques des habitants de Łódź en 1988 (K o s t r z e w a 1991); b - les excursions scolaires organisées par l'agence de tourisme „Panorama” dans les années 1994-1996 (D e n y s - S k u p i e ń s k a 1997) 
Miejscowości nadmorskie wybrane przez łodzian (pozbawionych na co dzień dostępu do walorów naturalnych) tworzą wąski pas wzdłuż wybrzeża Bałtyku od Świnoujścia na wyspie Wolin na zachodzie, po Krynicę Morską i Piaski na Mierzei Wiślanej na wschodzie. Najchętniej odwiedzano: Kołobrzeg Ustkę, Mielno, Jarosławiec, Rowy, Jastrzębią Górę, miejscowości Mierzei Helskiej, Trójmiasto. Wypoczynek w tym regionie łączy się z penetracją strefy brzegowej i najbliższych okolic. Wyjazdy nad morze stanowiły ok. $23 \%$ zrealizowanych wyjazdów przez pracowników wyższych uczelni i mieszkańców osiedla Stare Chojny oraz $33 \%$ wyjazdów zrealizowanych przez mieszkańców osiedla Radogoszcz Zachód. Region ten szczególnie preferowany był przez mieszkańców osiedla Stare Chojny. Miejscowości regionu nadmorskiego bogate w walory antropogeniczne i środowiska naturalnego to również cel wycieczek krajoznawczych łodzian zarówno tych realizowanych podczas pobytu nad morzem, jak i realizowanych z miejsca zamieszkania (rys. 2). Szczególnym zainteresowaniem cieszą się: Gdańsk, Gdynia, Sopot, Łeba, Słowiński Park Narodowy, Smołdzino, Kluki oraz Malbork, Elbląg, Frombork (D e n y s - S k u p i e ń s k a 1997, K o st r z e w a 1991). Łodzianie w strefie nadmorskiej (choć nielicznie) posiadają również działki letniskowe, gdzie najczęściej realizują wypoczynek letni, ale również i świąteczny (L a t o s i ń s k a 1997b).

Region górski cieszył się mniejszym powodzeniem wśród łodzian niż omawiany wcześniej region nadmorski. Obszary recepcji na obszarach górskich związane są głównie z Tatrami, Pieninami, Beskidem Sądeckim, Beskidem Śląskim i Żywieckim, natomiast w mniejszym stopniu z Sudetami oraz jeszcze mniejszym z Bieszczadami. Jako najliczniej odwiedzane miejscowości można wymienić: Zakopane, Bukowinę Tatrzańską, Muszynę oraz Szklarską Porębę i Karpacz - ośrodki wypoczynku zimowego, sportów zimowych. Mimo niezaprzeczalnych walorów turystycznych wszystkich obszarów górskich szczególnie preferowanym obszarem przez łodzian są Tatry, co wynika najprawdopodobniej z przyzwyczajeń wypoczynkowych oraz dobrej dostępności komunikacyjnej, dobrego zagospodarowania turystycznego, mody turystycznej itd. Łodzianie realizowali w regionach górskich od $20,5 \%$ wyjazdów pracowników wyższych uczelni do 15\% wyjazdów mieszkańców osiedla Radogoszcz Zachód. Miejscowości i regiony najczęściej odwiedzane przez wycieczki pokrywają się z wyznaczonymi regionami wypoczynku urlopowego. Dla nielicznych łodzian posiadających działki letniskowe $w$ miejscowościach górskich jest to również region wypoczynku weekendowego i świątecznego.

Obszary pojezierne cieszyły się najmniejszym powodzeniem wśród łodzian. Odwiedzane miejscowości są bardzo rozproszone na terenach Pojezierzy: Drawskiego, w Borach Tucholskich, na Pojezierzu Iławskim, Olsztyńskim, Suwalskim. Jak wynika z przeprowadzonych badań, walory turystyczne obszarów pojeziernych nie są znane bądź nie są doceniane przez ogół mieszkańców Łodzi, gdyż w regionie pojezierzy zrealizowano najmniej wyjazdów urlopowo-waka- 
cyjnych. Jest to uwarunkowane m.in. nierównomiernym (pomijając Wielkie Jeziora Mazurskie), wręcz słabym zagospodarowaniem turystycznym, jak również słabą dostępnością komunikacyjną. Zaskakująco mała jest w regionie pojezierzy, z wyjątkiem regionu kościerzyńsko-kartuskiego oraz Pojezierzy Brodnickiego i Olsztyńskiego, frekwencja wycieczek krajoznawczych (D e n y s -S k u p i eń s k a 1997, K o st r z e w a 1991). W obszarach leśnych Polski północnej i środkowo-zachodniej oraz w niewielkim stopniu Polski wschodniej, czyli w Puszczy Noteckiej, Rzepińskiej, Goleniowskiej, Borach Tucholskich oraz Puszczcy Białowieskiej i Knyszyńskiej (rys. 3) łodzianie chętnie przebywali na grzybobraniach (W i l u ś 1991). Region pojezierzy to również obszar wypoczynku urlopowego dla wędkarzy, szczególnie woj. suwalskie, olsztyńskie, bydgoskie, koszalińskie, gorzowskie (L e w a n d o s k i 1993).

Za tzw. ,inne regiony” Polski uznano w pracy obszary: Nizinę Wielkopolską, Nizinę Śląską, Nizinę Mazowiecką, Nizinę Podlaską, Wyżynę Lubelska, Roztocze, Wyżynę Małopolską oraz Jurę Krakowsko-Częstochowską. W większości są to obszary o dużej i niewielkiej przydatności dla wypoczynku oraz nieprzydatne. Pomimo mniejszej atrakcyjności niż regiony nadmorskie, górskie czy pojezierne wyjazdy w tzw. ,inne regiony" stanowiły często największy odsetek - od 20,9\% wyjazdów mieszkańców osiedla Stare Chojny do 30,6\% wyjazdów mieszkańców osiedla Radogoszcz Zachód. Najintensywniej wykorzystywanym obszarem wypoczynku był region łódzki z wyraźnie zakreślonym obszarem strefy podmiejskiej Łodzi (Grotniki, Sokolniki, Rosanów, Swędów), Zbiornika Sulejowskiego i obszarów nadpilicznych (Inowłódz, Spała, Borki, Smardzewice, Sulejów) oraz Zbiornika Jeziorsko i obszarów nadwarciańskich (Księże Młyny, Kościanki, Miłkowice, Pęczniew, Jeziorsko). Region łódzki pod względem przydatności do wypoczynku w prowadzonych waloryzacjach i rankingach określany jest mianem „,nieatrakcyjny” (W y r z y k o w s k i 1986) lub „niekorzystny" (Atlas środowiska geograficznego Polski, 1994, tabl. 66), co nie oznacza jednak, jak wykazały badania, że jego eksploatacja turystyczna jest ograniczona. Obszar wyznaczony od zachodu rzeką Wartą i Zbiornikiem Jeziorsko, od południowego wschodu rzeką Pilicą i Zbiornikiem Sulejowskim, a od północy krawędzią Wyżyny Łódzkiej - nazywany umownie Polską Środkową - od dawna stanowi zaplecze rekreacyjne dla mieszkańców Lodzi (L i s z e w s k i 1987, M a t c z a k 1981, 1985) ze względu na walory środowiska naturalnego obszarów nadwarciańskich i nadpilicznych. Nie odnotowano natomiast większego zainteresowania atrakcyjnymi dla wypoczynku regionami: Wyżyny Lubelskiej, Roztocza, Gór Świętokrzyskich i Jury Krakowsko-Częstochowskiej. Regiony te sa natomiast obszarem penetracji krajoznawczej łodzian (D e n y s -S k u p i eń s k a 1997, K o s t r z e w a 1991). Wyjazdy do Krakowa, Oświęcimia, Pieskowej Skały, Ojcowa, Wieliczki, Kazimierza Dolnego, Puław, Nałęczowa, Czarnolasu, jaskini Raj, Chęcin, Kielc to trasy wycieczek często uczęszczanych przez młodzież szkolną. W regionie Polski Środkowej realizowane są 

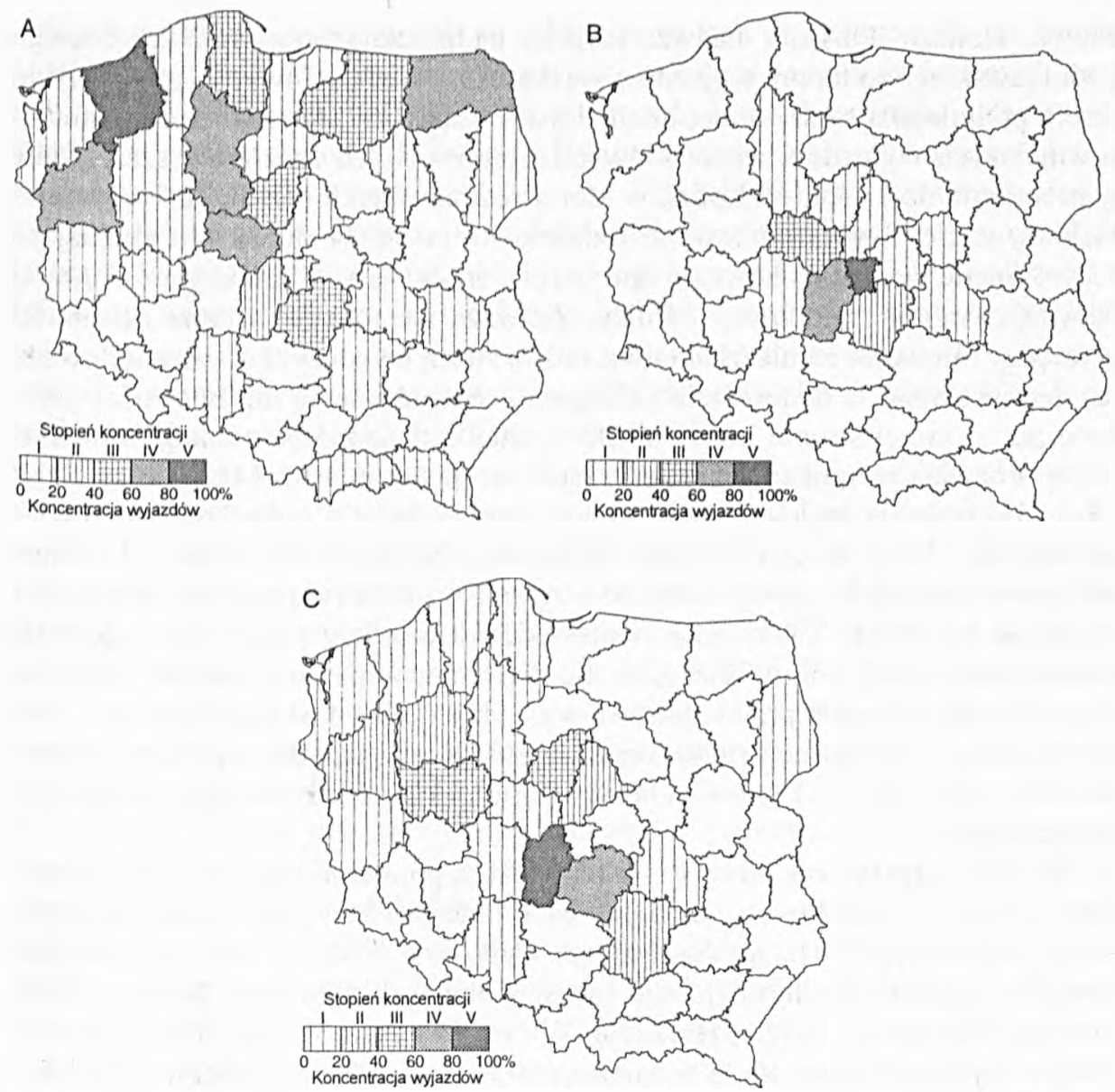

Rys. 3. Koncentracja wyjazdów na grzybobrania i wypraw wędkarskich; a - tereny wypraw wędkarskich mieszkańców aglomeracji łódzkiej w okresie wakacyjnym (L e w a n d o s k i 1993), b - tereny wypraw wedkarskich mieszkańców aglomeracji lódzkiej w okresie weekendowym (L e w a n d o s k i 1993), c - wyjazdy na grzybobrania pracowników łódzkich zakładów pracy (W i l uś 1991)

Dessin 3. La concentration des départs des amateurs des champignons et de la pêche: a - les terrains de la pêche à la ligne des habitants de l'agglomération de Łódź pendant les vacances ( $\mathrm{L}$ e w a n d o s k i 1993); b - les terrains de la pêche à la ligne des habitants de l'agglomération de Łódź pendant les week-ends ( $\mathrm{L}$ e w a n d o s k i 1993); c-les départs des travailleurs des établissements et des entreprises de Lódź pour la cueillette des champignons (W i l u ś 1991)

również wycieczki jednodniowe w najbliższe okolice Łodzi oraz do Warszawy, Arkadii, Nieborowa, Żelazowej Woli, Walewic, Niepokalanowa, Płocka, Torunia, Golubia Dobrzynia, Ciechanowa, oraz w części zachodniej i północno-zachodniej do Kruszwicy, Strzelna, Gniezna, Poznania, Rogalina, Biskupina, Gołu- 
chowa, Kalisza. Obszary nadwarciańskie, nadpiliczne oraz woj. konińskiego i włocławskiego to tereny wyjazdów wędkarskich weekendowych i urlopowych. Strefa podmiejska Łodzi oraz obszar Polski Środkowej stanowi strefę najintensywniejszych wyjazdów weekendowych i letniskowych łodzian, a szczególnie w promieniu do $24 \mathrm{~km}$ od Łodzi, w której realizowanych jest aż $82,7 \%$ wszystkich wyjazdów wypoczynkowych łodzian, strefa od 24 do $33 \mathrm{~km}$ skupiająca $12,4 \%$ ruchu wypoczynkowego oraz strefa $50-60 \mathrm{~km}$, o atrakcyjności której decydują walory rzek Warty i Pilicy. Zauważa się również istotne zależności pomiędzy miejscem zamieszkania w Lodzi a strefą wypoczynku weekendowego czy letniskowego, a mianowicie najczęściej odwiedzane są miejscowości położone po tej samej stronie Łodzi, w której znajduje się miejsce stałego zamieszkania. Pozwala to unikać przemieszczania się przez miasto. Mieszkańcy Bałut i Polesia preferują region zachodni i północny, Widzewa - wschodni, Górnej południowy. Mieszkańcy centralnie położonego Śródmieścia preferują kierunek północno-wschodni i południowy ze względu na dobrą dostępność komunikacyjną (M a t c z a k 1994). Lasy województwa piotrkowskiego (lasy spalskie) i sieradzkiego (lasy doliny Warty, okolic Wielunia, Widawy i Sieradza) były i sa obszarem skupiającym prawie połowę wyjazdów łodzian na grzybobrania. Poza wymienionymi w Polsce Środkowej duże znaczenie mają dla miłośników grzybobrania lasy województw: włocławskiego, płockiego, konińskiego, kaliskiego, kieleckiego.

Podróże zagraniczne cieszyły się największą popularnością wśród pracowników wyższych uczelni (w szczególności pracowników naukowo-dydaktycznych), stanowiąc $15,4 \%$ zrealizowanych wyjazdów. Podczas wyjazdów odwiedzano najczęściej i najliczniej kraje i wyspy europejskie: Francję, Włochy (m.in. Sycylię), Hiszpanię, Belgię, Holandię, Wielką Brytanię, Austrię, Maltę, Szwajcarię oraz mniej licznie kraje pozaeuropejskie: Izrael, Egipt, Australię, Kanadę, USA, Brazylię, Meksyk. Głównym motywem podróży zagranicznych była chęć poznania stolic krajów europejskich oraz pobyt wypoczynkowy w basenie Morza Śródziemnego jak również w wysokich górach (Alpy), w celu uprawiania turystyki kwalifikowanej (narciarstwo, turystyka piesza górska). Dla porównania, w końcu lat osiemdziesiątych wyjazdy zagraniczne organizowane przez łódzkie biura podróży kierowały się do krajów europejskich w 97,85\% wyjazdów zagranicznych, w tym najliczniej do krajów Europy środkowej, wschodniej i śródziemnomorskiej (M a t c z a k 1994, R o g a ls k i 1995). Obecnie zostały wykreowane nowe kierunki, do których niewątpliwie - oprócz ciepłych krajów europejskich basenu Morza Śródziemnego - dołączyły kraje afrykańskie (Tunezja, Maroko, Egipt), Turcja, Grecja oraz Wyspy Kanaryjskie. Dużą popularnością cieszą się nadal wycieczki do stolic krajów europejskich: Paryża, Pragi, Budapesztu, Wiednia.

W celu podsumowania wyboru przestrzeni urlopowo-wakacyjnej posłużono się metodą koncentracji. Korzystający w 1994 r z wyjazdów urlopowo-waka- 
cyjnych łodzianie wypoczywali w miejscowościach rozproszonych na terenie całego kraju. Współczynnik koncentracji kształtujący się wśród badanych grup na poziomie od 0,66 do 0,41 wskazuje na średni poziom koncentracji, czyli dość znaczne rozproszenie wypoczywających w przestrzeni. Największa koncentracja wypoczywających zaznacza się na terenie 12 województw: czterech nadmorskich (gdańskiego, słupskiego, koszalińskiego, szczecińskiego), trzech górskich (nowosądeckiego, jeleniogórskiego, bielskiego) oraz pięciu Polski Środkowej łódzkiego, piotrkowskiego, sieradzkiego, konińskiego oraz włocławskiego. Wyjazdy łodzian do miejscowości obszarów pojeziernych wykazują duże rozproszenie. Najliczniej odwiedzane w tej strefie są: suwalskie, elblaskie (miejscowości na Mierzei Wiślanej), olsztyńskie i bydgoskie.

Wypoczynek urlopowy to również okazja do penetracji najbliższych okolic miejsca wypoczynku. Można zauważyć, że im dalej od Łodzi, od terenów znanych, wzrasta aktywność poznawcza urlopowicza. Przy okazji pobytu w miejscowościach wypoczynkowych odwiedzano miejscowości sąsiednie bądź znajdujące się na trasie przejazdu, zajmujące często miejsce szczególne na mapie turystycznej kraju, także o znaczeniu międzynarodowym. Wybrane miejscowości czy regiony odgrywają różnorodną rolę w ruchu turystycznym, będąc dla jednych przestrzenią eksploracji, dla innych zaś penetracji, asymilacji, kolonizacji czy nawet urbanizacji, co - jak podaje S. L i s ze w s k i (1995b) - wynika z pełnionych przez nie funkcji: poznawczych, poznawczo-wypoczynkowych, wypoczynkowo-poznawczych, wypoczynkowych czy wręcz mieszkaniowych. Wypoczynek w obszarach Polski Środkowej oraz w pasie nadmorskim ogranicza się głównie do pobytu w miejscu wypoczynku i penetracji najbliższych okolic, w regionach górskich i pojeziernych łączy się z penetracją większych terenów. Może to wskazywać na różny charakter tego wypoczynku: nad morzem - bierny, w Polsce Środkowej - czynny, ale w jednym miejscu (pobyt na działce, pobyt u rodziny), natomiast w górach i nad jeziorami - aktywny, czynny, poznawczy. Można więc mówić o wypoczynku ,punktowym” i „powierzchniowym".

\section{WNIOSKI}

1. Porównując wyniki badań z połowy lat osiemdziesiątych (D z i e g i e ć, L is ze w s k i 1985, M a tc zak 1994) z wynikami badań prezentowanych prac (rys. 1) można pokusić się o stwierdzenie, iż zasadnicze znaczenie w przestrzeni turystycznej łodzian posiada nadal przestrzeń o zasięgu krajowym. Porównanie obszarów koncentracji pozwala zauważyć, iż wykrystalizowały się regiony wypoczynku krajowego, które na mapie kraju pozostają niezmienne od kilkunastu lat, różny jest natomiast stopień natężenia badanego zjawiska. Naj- 
większe znaczenie wypoczynkowe dla łodzian mają: region nadmorski, region Polski Środkowej oraz górski z wyraźnie dominującym województwem nowosądeckim (rys. 1).

2. Badania prowadzone w połowie lat dziewięćdziesiątych wskazują na stale rosnace znaczenie strefy podmiejskiej (szczególnie w zakresie wypoczynku weekendowego) i regionu Polski Środkowej traktowanego jako zaplecze wypoczynkowe (wyjazdy urlopowe i weekendowe) łodzian. Dla niektórych jest to jedyny region wypoczynku, dla innych zaś kolejnego wyjazdu turystycznego po uprzednim wypoczynku nad morzem czy w górach. Należy podkreślić rosnącą rolę najatrakcyjniejszych obszarów regionu łódzkiego jako przestrzeni turystycznej łodzian, zwłaszcza doliny Warty i zbiornika Jeziorsko, doliny Pilicy i Zalewu Sulejowskiego oraz północnej części Wyżyny Łódzkiej.

3. W zakresie wyjazdów wycieczkowych od lat pozostaje wyznaczony przez odwiedzane miejscowości szlak przebiegający z północy na południe od Gdańska po Zakopane. Łodzianie na ogół nie znają obszaru Polski północno-wschodniej i wschodniej oraz północno-zachodniej i zachodniej. Region Dolnego Śląska, Ziemi Lubuskiej, Podlasia i Polesia nadal pozostaja „białymi plamami” dla mieszkańców Łodzi (rys. 2).

4. Największe zmiany zachodzą w zakresie wyjazdów zagranicznych zarówno wypoczynkowych, jak i wycieczkowych. Ze względu na zniesienie ograniczeń paszportowych kraje odległe stają się coraz bardziej dostępne. Zmieniają się kierunki wyjazdów zagranicznych, kreowane dziś głównie przez biura turystyczne, a nie jak to było dawniej, przez zakłady pracy i FWP (M i ą z e k K a j k o w s k a 1988). W propozycji biur podróży, poza ofertą krajową i standardową zagraniczną, znajdują się najdalsze zakątki świata. To co kiedyś było marzeniem, staje się rzeczywistością. W związku z łatwiejszą dostępnością krajów położonych nad ciepłym morzem wydłuża się sezon turystyczny łodzian trwajacy od maja do października.

5. Zdecydowanie od początku lat dziewięćdziesiątych zmienia się organizator wyjazdów turystycznych. Miejsce zakładu pracy, szkoły, organizacji zajęły biura turystyczne oraz indywidualna organizacja wyjazdów. W Lodzi są to w większości biura pośredniczące w sprzedaży oferty wykreowanej przez touroperatorów.

6. Przestrzeń turystyczna nie jest dostępna w jednakowym zakresie dla każdego człowieka. Na wybór przestrzeni turystycznej ma wpływ zespół czynników demograficznych, społeczno-zawodowych, ekonomicznych oraz geograficznych i trudno jednoznacznie określić, który z nich jest czynnikiem dominującym. Dotyczy to zarówno analizy wyboru jednostki, jak i wydzielonej grupy czy całej badanej populacji. Równie istotny - a niejednokrotnie decydujący - wpływ na wybór przestrzeni wypoczynkowej ma czynnik osobowościowy. Jego specyfika i charakter uniemożliwiają jego analizę w ujęciu geograficznym. Zdaniem autorki największy wpływ na zachowania przestrzenne mają czynniki określone 
mianem społeczno-zawodowych, a szczególnie wykształcenie, bowiem można wykazać ścisłą zależność pomiędzy poziomem wykształcenia, wskaźnikiem aktywności turystycznej, preferencjami w zakresie miejsc wypoczynku oraz poziomem zaspokojenia potrzeb wypoczynkowych. Im wyższe wykształcenie tym swobodniejszy wybór przestrzeni turystycznej. Druga grupa czynników mających duży wpływ na wybór przestrzeni to kondycja finansowa oraz poziom zamożności. Jako trzecią grupę czynników należy wymienić czynniki geograficzne, czyli miejsce zamieszkania i pochodzenia oraz miejsce lokalizacji posiadanej działki letniskowej czy ogródka działkowego. Najwięcej trudności sprawia jednoznaczne określenie związków i zależności pomiędzy cechami demograficznymi a wyborem przestrzeni turystycznej (L a t o s i ń s k a 1997b).

\section{PIŚMIENNICTWO}

Atlas środowiska geograficznego Polski, 1994, PAN, Instytut Geografii i Przestrzennego Zagospodarowania, Warszawa, tabl. 66.

B a I c e r a k A., 1996, Turystyka i wypoczynek nauczycieli zgierskich szkót podstawowych i średnich, maszynopis pracy magisterskiej, Katedra Geografii Miast i Turyzmu UŁ, Łódź.

B a r t k o w s k i T., 1974, Zastosowanie geografii fizycznej, Warszawa-Poznań.

B e d n a r s k a D., 1978, Miejsca wypoczynku nauczycieli szkót średnich dzielnicy tódź-Widzew w roku 1977, maszynopis pracy dyplomowej wykonanej na Podyplomowym Studium Turystyki przy Instytucie Geografii Ekonomicznej i Organizacji Przestrzeni UŁ, Katedra Geografii Miast i Turyzmu UŁ, Łódź.

B e r e z o w s k i S., 1969, Struktura przestrzenna gospodarki narodowej Polski, Warszawa.

B r e c ła w i k K., 1988, Turystyka w systemowej koncepcji potrzeb, „Problemy Turystyki”, nr 2.

C h o j n i c k i Z., 1974, Przestrzeń spoleczno-ekonomiczna Polski, „Biuletyn KPZK PAN”, z. 84 .

D e n y s - S k u p i e ń s k a K., 1997, Funkcja poznawcza wycieczek szkolnych organizowanych przez biuro turystyczne Panorama, maszynopis pracy magisterskiej, Katedra Geografii Miast i Turyzmu Ut, Łódź.

D o m a ń s k i R., 1965, Problematyka metodologiczna ogólnej teorii przestrzeni ekonomicznej, „Prace Geograficzne IGiPZ PAN”, nr 37.

D o m a ń s k i R., 1990, Zasady geografii spoleczno-ekonomicznej, PWN, Warszawa- Poznań.

D r a m o w i c z K., 1984, Przestrzeń w geografii - wciqż nowy stary problem, „Przegląd Zagranicznej Literatury Geograficznej", z. 3-4.

D r z e w i e c k i M., 1983, Uwagi o zakresie pojęć: ,turystyka”, ,rekreacja”, ,wczasy”, „wypoczynek”, „Przegląd Geograficzny”, z. 1.

D z i e g i e ć E., L i s z e w s k i S., 1985, Wyjazdy wakacyjno-urlopowe mieszkańców Lodzi, „Acta Universitatis Lodziensis", Turyzm 1.

D z i e g i e ć E., 1995, Urbanizacja turystyczna terenów wiejskich w Polsce, „Turyzm”, t. 5, z. 1.

D z i e w o ńs k i K., 1967a, Baza ekonomiczna i struktura funkcjonalna miast. Studium pojęć, metod i ich zastosowań, „Prace Geograficzne IGiPZ PAN”, nr 63.

D z i e w o ń s k i K., 1967b, Teoria regionu ekonomicznego, „Prace Geograficzne IGiPZ PAN”, nr 39.

D z i e w o ń s k i K., 1988, Teoretyczne problemy gospodarki przestrzennej, „Biuletyn KPZK PAN", z. 138. 
„Dziennik Ustaw Rzeczypospolitej Polskiej”, nr 65, z dnia 27 września 1990 r.

G a w o r e c k i W., 1994, Turystyka, PWE, Warszawa.

G r z e s z c z a k J., 1971, Koncepcje polaryzacyjne w przestrzennym zagospodarowaniu kraju (na przyktadzie Francji), ,Studia KPZK PAN”, t. 36.

$\mathrm{G}$ w a d e r a M., 1996, Turystyka i wypoczynek pracowników EZPB im. Obrońców Pokoju „Uniontex”, maszynopis pracy magisterskiej, Katedra Geografii Miast i Turyzmu UL, Lódź.

Hajn Z., S e w e ry ńs k i M., 1996, Kodeks pracy. Stan prawny z 2.02.1996 r., Dz.U., nr 24, poz. 110, PPU PARK, Kraków.

$\mathrm{H}$ u s b a n d s W. C., 1983, Tourist space and touristic attraction, an analysis of the destination choices of European travellers, „Leisure Sciences”, vol. 5, s. 285-307.

J a ło w i e c k i B., 1986, Spoleczne funkcje i znaczenie centrum miasta, [w:] Centrum miastacentrum Wroclawia, Wrocław.

J a ło w i e c k i B., 1988, Spoteczne wytwarzanie przestrzeni, KiW, Warszawa.

K e g l e r D., 1990, Wypoczynek urlopowy rzemieślników Lodzi, maszynopis pracy magisterskiej, Katedra Geografii Miast i Turyzmu UŁ, Lódź.

K ol o d z i e j c z y k M., 1997, Przedsiębiorstwo Turystyczne "Lódż” Centrum Ushug Turystycznych jako organizacja turystyczna $i$ wypoczynkowa mieszkańców Łodzi i województwa, maszynopis pracy magisterskiej, Katedra Geografii Miast i Turyzmu UŁ, Łódź.

K o p e r k i e w i c z A., 1980, Miejsca i formy wypoczynku wakacyjnego nauczycieli szkót podstawowych zatrudnionych na terenie Łodzi $i$ woj. piotrkowskiego w roku 1979, maszynopis pracy dyplomowej, Katedra Geografii Miast i Turyzmu UŁ, Łódź.

K o s t r z e w a J., 1991, Wyjazdy wycieczkowe mieszkańców todzi jako forma wypoczynku poznawczego, ,Turyzm”, z. 2.

K r z y mow s k a - K o s t r o w i c k a A., 1980, Terytorialny system rekreacyjny. Analiza struktury i charakteru powiqzań (studium teoretyczno-metodyczne), „Prace Geograficzne”, Uniwersytet Warszawski, z. 138.

Krzy mowska-Kostrow i c k a A., 1995, Zarys geoekologii rekreacji, t. 2, UW, Warszawa.

L a t o s i ń s k a J., 1997a, Przestrzeń urlopowo-wakacyjna jako obszar realizacji potrzeb wypoczynkowych mieszkańców dużego miasta. Na przykładzie grupy pracowników wyższych uczelni Łodzi, ,Turyzm”, t. 7, z. 1.

L a t o s i ń s k a J., 1997b, Przestrzeń urlopowo-wakacyjna pracowników wyższych uczelni Łodzi, maszynopis pracy doktorskiej, Katedra Geografii Miast i Turyzmu UŁ, Łódź.

L e s z c z y c k i S., 1972, Pojęcie czynnika przestrzeni i jego rola we wspólczesnej gospodarce, [w:] Elementy teorii planowania przestrzennego, Warszawa.

L e w a n d o w s k i R., 1993, Wędkarstwo jako forma turystyki kwalifikowanej mieszkańców aglomeracji łódzkiej, maszynopis pracy magisterskiej, Katedra Geografii Miast i Turyzmu Ut, Łódź.

L i s z e w s k i S., 1987, Geneza i rozwój osadnictwa wypoczynkowego w otoczeniu Łodzi, „Acta Universitatis Lodziensis", Turyzm, nr 3.

L i s z e w s k i S., 1995a, Zróżnicowanie przestrzenne poziomu i jakości warunków życia ludności w aglomeracjach miejskich (Program badañ, pierwsze wyniki), „Acta Universitatis Lodziensis", Folia geographica, nr 20, s. 207-219.

L i s zew sk i S., 1995b, Przestrzeń turystyczna, „Turyzm”, t. 5, z. 2, s. 87-103.

M a t c z a k A., 1981, Tereny wypoczynkowe w strefie podmiejskiej Łodzi, „Miasto”, nr 6.

M a t c z a k A., 1985, Funkcja wypoczynkowa strefy podmiejskiej Lodzi, ,Acta Universitatis Lodziensis", Folia geographica, nr 5 .

M a t c z a k A., 1992, Model badań ruchu turystycznego. Studium metodologiczne, „Acta Universitatis Lodziensis".

M a t c z a k A., 1993, Wykorzystanie wypoczynkowe terenów zielonych miasta Lodzi, ,Acta Universitatis Lodziensis", Folia geographica, nr 19. 
M a $\mathrm{c}$ z a k A., 1994, Rola turystyki $i$ wypoczynku w integracji i rozwoju regionu tódzkiego, [w:] Studium wiedzy o regionie lódzkim. Wybrane problemy, ŁTN, Łódź.

M i ą z e k-K a j k ow s k a M., 1988, Struktura przestrzenna i formy wypoczynku urlopowo-wakacyjnego i sobotnio-niedzielnego mieszkańców osiedla im. S. Batorego w Łodzi, maszynopis pracy magisterskiej, Katedra Geografii Miast i Turyzmu UŁ, Łódź.

M i c h a l a k A., 1998, Turystyka $i$ wypoczynek mieszkańców osiedla ,Pojezierska" $w$ Lodzi, maszynopis pracy magisterskiej, Katedra Geografii Miast i Turyzmu UŁ, Łódź.

M i o s s e c J. M., 1977, Un modèle de l'espace touristique, „L'Espace Geographique”, no 1.

O s t r o w s k i S., 1980, Rozwój potrzeb turystyczno-wypoczynkowych spoteczeństwa, „Problemy Turystyki", nr 2.

O t o k S., 1987, Geografia spoleczna, PWN, Warszawa.

P a w I a k M., 1990, Wyjazdy wycieczkowe organizowane przez zakłady pracy, jako forma wypoczynku mieszkańców, maszynopis pracy magisterskiej, Katedra Geografii Miast i Turyzmu UŁ, Łódź.

Prze cławs k i K., 1994, Turystyka a świat wspótczesny, UW, Warszawa.

R o g a l ew s k i O., 1977, Zagospodarowanie turystyczne, WSiP, Warszawa.

R o g a 1 s k i W., 1995, Weryfikacja zagranicznej oferty turystycznej PT „Grand Tour” w sezonie letnim 1994 roku przez mieszkańców Lodzi, maszynopis pracy magisterskiej, Katedra Geografii Miast i Turyzmu UŁ, Łódź.

S a $1 \mathrm{t}$ a r s k a M., 1991. Wyjazdy zagraniczne mieszkańców Lodzi w 1990 roku, maszynopis pracy magisterskiej, Katedra Geografii Miast i Turyzmu UŁ, Łódź.

S i b e r a W., 1977, Organizacja przestrzenna wypoczynku i turystyki pracowników ZPP. im. M. Buczka "Zenit" w Lodzi, maszynopis pracy magisterskiej, Katedra Geografii Miast i Turyzmu UŁ, Łódź.

S t a c how s k i J., 1993, O pojmowaniu przestrzeni $w$ geografii turyzmu, „Acta Universitatis Nicolai Copernici", Geografia XXIV, Toruń, s. 172.

S t a $1 \mathrm{~s} \mathrm{k} \mathrm{i} \mathrm{M.,} \mathrm{1984,} \mathrm{Uzytkowanie} \mathrm{ziemi} w$ turystyce, „Przegląd Zagranicznej Literatury Geograficznej", z. 2, s. 139-148.

S z c z e g i e I s k a M., 1980, Zagospodarowanie czasu wolnego ZPDz „Olimpia” w Łodzi, maszynopis pracy magisterskiej, Katedra Geografii Miast i Turyzmu UŁ, Łódź.

S z y m a ń s k a A., 1995, Model turystyki i wypoczynku mieszkańców osiedla Radogoszcz Zachód w Łodzi, praca magisterska wykonana w Katedrze Geografii Miast i Turyzmu UŁ, Łódź.

Turystyka w 1994 r., 1995, GUS, Warszawa.

W a I b o r s k a E., 1995, Turystyka $i$ wypoczynek uczniów XXV Liceum Ogólnoksztatcqcego $w$ Lodzi, maszynopis pracy magisterskiej, Katedra Geografii Miast i Turyzmu UŁ, Łódź.

W a 11 i s A., 1983, Przestrzeń jako wartość. Księga pamiqtkowa Profesora J. Chatasińskiego, Wroclaw.

W a 11 i s A., 1990, Socjologia przestrzeni, Niezależna Oficyna Wydawnicza, Warszawa.

W a I m s l ey D. J., L ew is G. J., 1997, Geografia czlowieka. Podejścia behawioralne, PWN, Warszawa.

W a rszyń sk a I., J a c k ow sk i A., 1978, Podstawy geografii turyzmu, PWN, Warszawa.

W a r s z y ń s k a J., 1986, Problemy badawcze geografii turyzmu, „Folia Geographica”, ser. Geographica Oeconomica, vol. 19, s. 59-63.

W a w r z y n i a k S., 1988, Wypoczynek wakacyjno-urlopowy w Polsce. Wspótczesne tendencje w świetle badań wykorzystania bazy noclegowej, „Problemy Turystyki”, nr 3.

W i I u ś R., 1991, Wyjazdy na grzybobrania, jako forma wypoczynku mieszkańców miast. Przykład Łodzi, ,Turyzm”, t. 1, z. I.

W i n i a r s k i R., 1988, Motywacje turystyczne: struktura $i$ spoteczne uwarunkowania, „Problemy Turystyki", nr, 2.

W o j c i e c h ow s k i K. H., 1986, Problemy percepcji i oceny estetycznej krajobrazu, UMCS, Lublin. 
W y r z y k o w s k i J., 1986, Geograficzne uwarunkowania rozwoju urlopowej turystyki wypoczynkowej w Polsce, „Acta Universitatis Wratislaviensis”, Studia Geograficzne XLIV.

Z a w a d z k i M., 1990, Uczestnictwo ludności Polski w wyjazdach urlopowo-wakacyjnych, „Biuletyn Informacyjny”, nr 4, s. 4-14.

Z d e b s k i J., 1996, Elementy psychologii turystyki, [w:] Pilotaż wycieczek zagranicznych, Kurek Z. (red.), PUS „Mentor”, Kraków.

Z m y s lo w s k a E., 1994, Turystyka i wypoczynek mieszkańców osiedla Stare Chojny w Lodzi, maszynopis pracy magisterskiej, Katedra Geografii Miast i Turyzmu UŁ, Lódź.

Dr Jolanta Latosińska

Katedra Geografii Miast i Turyzmu

Uniwersytet Łódzki

al. Kościuszki 21

90-418 Łódź
Wpłynęlo: 18 września $1998 \mathrm{r}$.

\section{RÉSUMÉ}

Depuis quelques années, ce sont les recherches sur l'espace touristique qui constituent un des courants des intérêts de la géographie du tourisme. Dans le travail présenté l'espace touristique est identifié avec localités et les terrains touristiques en dehors des localités où l'on est installé à demeure, tracés pendant les départs touristiques de congé, de vacances, de week-ends et d'excursion. Au cas des habitants d'une grande agglomération, où les conditions de vie et de travail sont toujours difficiles et incommodes, le repos loin de la maison est non seulement utile, mais avant tout indispensable.

Vu le manque des donnés illustrant le problème du repos et des préférences spatiales des habitants de Łódź sur une échelle de la ville, en analysant l'espace touristique au milieu des années quatre-vingt-dix, on s'est servi de recherches partielles de A. S z y m a ń s k a (1995), A. Z m y s ł ow s k a (1994) et J. L a t o s i ń s k a (1997b), faites parmi les habitants de deux cités résidentielles Radogoszcz Zachód et Stare Chojny et les travailleurs des écoles supérieures de Łódź. Dans le centre géographique de Łódź, la tradition des recherches sur le repos des habitants de la ville remonte à la fin des années soixante-dix. Depuis ce temps ont paru plus de dix travaux théoriques et applicables enfermant l'analyse de la disposition spatiale, essentielle pour le sujet abordé, les régions de la concentration des lieux du repos de congé annuel, de week-end ou d'excursion des habitants de Lódź selon les groupes sociaux, professionnels et des habitants des cités résidentielles, ainsi que les directions préférées des départs de repos et d'instrucion proposées par les agences touristiques à Lódź.

En analysant l'espace touristique des habitants de Łódź, on peut remarquer que ceux-ci suivent les chemins battus. En comparant les résultats des recherches de la deuxième moitié des années quatre-vingts (D z i e g i e ć, L i s z e w s k i 1985) avec ceux des travaux présentés on est tenté de constater que l'espace touristique à l'étendue du pays a de l'importance pour les habitants de Łódź. Quelques régions de repos, qui se sont cristallisées, restent inchangées depuis plusieurs années sur la carte du pays, change seulement le degré de l'intensification du phénoméne analysé. Les habitants de Łódź préférent se reposer au bord de la mer Baltique (y passant le congé et les vacances), dans la région de la Pologne Centrale (le repos de congé et de week-end, aux endroits où l'on pêche et cueille les champignons) et les régions montagneuses avec les terrains de ski (le repos de congé et de vacances). La voïvodie de Nowy Sącz y joue le rôle dominant. La région de lacs et les voyages à l'étranger (de 15 à 6,4\% des départs dans les groupes examinés) ne sont pas très populaires parmi les habitants de Łódź. 
Les recherches faites dans la moitié des années quatre-vingt-dix démontrent l'importance croissante toujours de la zone suburbaine (surtout pour le repos de week-end) et de la région de la Pologne Centrale, traitée comme le terrain facilement accessible avec la vallée de Warta, le bassin de Jeziorsko, la vallée de Pilica, la submersion de Sulejów et la partie nord du plateau de Lódź. Pour les uns c'est la région unique de repos, pour les autres - du départ successif aprés les vacances passées au bord de la mer, à la montagne ou à l'étranger.

Quant aux départs d'excursion, depuis longtemps reste le même itinéraire, tracé par les loclités visitées, parcourant du Nord vers le Midi de Gdańsk à Zakopane. Les habitants de Łódź ne connaissent pas la Pologne nord-est et est, la Pologne nord-ouest et ouest (ces terrains constituent des taches blanches sur la carte chorographique).

Les départs à l'étranger, ainsi ceux de repos que ceux d'excursion subissent des changements considérables. Les passeports étant accessibles, on peut aller où l'on veut. Les directions des départs changent. Ce sont les agences touristiques qui s'en occupent. L'accessibilité des pays situés aux bords des mers chaudes prolongent la saison touristique des habitants de Łódz, qui dure du mois de mai jusqu'au mois d'octobre. Dès le commencement des années quatre-vingt-dix change l'organisateur des départs touristiques. Ce sont les agences touristiques qui ont remplacé les responsables agissant dans les établisse - ments, les écoles, les organisations et le Fonds de Vacances des Salariés (à Lódź elles servent d'intermédiaire en vente des offres élaborées par les opérateurs). L'organisation des départs individuels est aussi possible.

L'espace touristique n'est pas accessible à tout le monde au même degrée. Le choix de celuici est influencé par l'ensemble de facteurs démographiques, socio-professionnels, économiques et géographiques. Il est difficile de dire d'une façon équivalente lesquels d'entre eux sont dominants. Selon l'auteur, ce sont les facteurs socio-professionnels (avant tout l'instruction), économiques (la condition financiére et le niveau de l'aisance), géographiques (le lieu d'habitation, la possession d'une parcelle de terre) qui ont la plus grande influence sur les comportements spatiaux. La détermination des liaisons et des dépendances entre les traits démographiques et le choix de l'espace touristique occasionne le plus de difficultés. Aussi principale et souvent décisive est l'influence du facteur personnel sur le choix de l'espace touristique.

Traduit par Lucjan Kowalski

\section{SUMMARY}

For several years one of the main problems in the geography of tourism has been research into the tourist space. In this article the tourist space is identified as tourist places and areas outside the place of permanent residence, marked during holiday, weekend and excursion trips. In the case of the inhabitants of a large agglomeration where living and working conditions have always been difficult, one can speak not only about the need but even about the necessity to rest outside the place of permanent residence.

Due to the lack of information illustrating the phenomenon of recreation and spatial preferences of Lodz inhabitants, in the analysis of their tourist space in mid 1990s, results of the research carried out by A. S z y mań s k a (1995), E. Z m y s ło w s k a (1994) and J. L a t o s i ń s k a (1997b) were used. Their research concerned the inhabitants of housing estates of Radogoszcz West and Old Chojny, as well as university employees. In the Lodz geographical centre the tradition of research into the recreation of Lodz inhabitants dates back to the 1970s. Since then several theoretical and applied analyses of spatial distribution have been made, as well as a description of the regions of holiday, weekend and excursion recreation according to social, 
professional groups and groups of housing estates inhabitants. Also preferred directions of holiday trips offered by Lodz tourist agencies were discussed.

Analysing the tourist space of Lodz inhabitants one can notice that they travel along well known tourist and holiday routes. Comparing the results of research from mid 1980s (D z i e $\mathrm{g}$ i e ć, L i s z e w s k i 1985) with the results of work under discussion from the 1990s, one can state that the basic significance in the tourist space of Lodz inhabitants is ascribed to the space attractive nationwide ( $80-95 \%$ of trips in the groups under study). Regions of recreation have emerged which on the map of the country have remained unchanged for several years, but the intensity of the phenomenon differs. For the inhabitants of Lodz the most significant region, as far as recreation is concerned, is the seaside region (mainly as the area of summer holiday recreation), the region of Central Poland (holidays and weekends, mushroom picking and fishing area), as well as the mountain region (holidays, skiing), with clearly predominant Nowy Sacz voievodship. The least significant region in this respect is the lake district and tourism abroad (from $15 \%$ to $6.4 \%$ in the groups under study).

The research carried out in the 1990s point to the continuously growing significance of the suburban zone (especially as regards the weekend recreation) and the region of Central Poland, treated as the main recreation area for the inhabitants of Lodz, and in particular its most attractive areas: Warta valley and Jeziorsko reservoir, Pilica valley and Sulejow Bay, as well as the northern part of Lodz Highland. For some it is the only region of recreation, for others it is where they travel having previously been at the seaside, in the mountains or abroad.

As far as trips are concerned, there exists a route marked by the places which are visited, running from the north southwards, from Gdansk to Zakopane. The inhabitants of Lodz do not know the north-eastern, eastern, north-western and western parts of Poland (these areas have been white spots on the tourist maps of Lodz inhabitants for years).

The biggest changes occur where traveling abroad is concerned, both recreationally and in the form of organised trips. Since passports can be easily obtained, faraway countries are becoming widely available. Destinations promoted by travel agencies are changing. As countries on warm seas are easy to travel to, the Lodz inhabitants' holiday season is becoming longer and lasts from May to October.

Since the beginning of the 1990s the organizer of travel abroad has decidedly changed. The place of the employer, school, organization, Workers' Holidays Fund has been taken over by tourist agencies (in Lodz they are mostly agencies working as the middleman in the sale of an offer created by tour creators) and individual organization of trips.

The tourist space is not equally accessible for every person. The choice of the tourist space depends on a group of demographic, social and vocational, economic and geographical factors, and it is hard to decide which is the determining one. According to the author, the social and vocational factors (mainly education), as well as economic (finances) and geographical (place of residence, owning a summer house) factors have the greatest influence on the spatial behaviour. The most difficult proves to be defining relationships between the demographic features and the choice of tourist space. The personality factor has an equally important, and often deciding influence on the choice of the recreational space. 